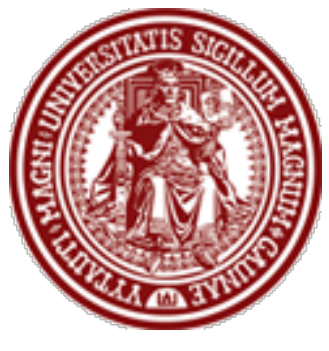

BALTIC JOURNAL OF LAW \& POLITICS

A Journal of Vytautas Magnus University

VOLUME 13, NUMBER 2 (2020)

ISSN 2029-0454

sciendo

Cit.: Baltic Journal of Law \& Politics 13:2 (2020): 135-158

https://content.sciendo.com/view/journals/bjlp/bjlp-

overview.xml

DOI: $10.2478 /$ bjlp-2020-0014

\title{
PARTY AUTONOMY IN THE CONTEXT OF JURISDICTIONAL AND CHOICE OF LAW RULES OF MATRIMONIAL PROPERTY REGULATION
}

\author{
Agnè Limantè \\ Chief Researcher; Dr. \\ Law Institute, Lithuanian Centre for Social Sciences (Lithuania) \\ Contact information \\ Address: Ankštoji g. 1A, LT-01109 Vilnius, Lithuania \\ Phone: +370 52497591 \\ E-mail address: agne.limante@teise.org

\section{Neža Pogorelčnik Vogrinc} \\ Assistant Professor; Dr. \\ University of Ljubljana, Faculty of Law (Slovenia) \\ Contact information \\ Address: Poljanski nasip 2, 1000 Ljubljana, Slovenia \\ Phone: +38614203151 \\ E-mail address: neza.pogorelcnik@pf.uni.lj.si
}

Received: November 23, 2020; reviews: 2; accepted: December 30, 2020.

\section{ABSTRACT}

In 2019, the EU Member States started applying the Matrimonial Property Regulation, which concerns the property regimes of international marriages. This regulation is aimed at helping couples manage their property and divide it in case of divorce or the death of one spouse. One of the main features of this regulation is its openness to the parties' choice. The 
parties are enabled - in cases foreseen in the regulation - to grant jurisdiction to the court of a Member State of their choice, as well as to choose the law applicable to their matrimonial property regime. Since this regulation is new and the track record of its application is rather short, the limits of party autonomy allowed under the regulation and its advantages still involve a high degree of uncertainty. This article provides an in-depth analysis of party autonomy as provided for in the Matrimonial Property Regulation. In addition, it scrutinises the issue of party autonomy in the Succession Regulation, which often directly interacts with the Matrimonial Property Regulation.

\section{KEYWORDS}

Matrimonial Property Regulation, Succession Regulation, matrimonial property, party autonomy, prorogation of jurisdiction, choice of law

\section{NOTE}

This publication is a deliverable of the project "E-training on EU Family Property regimes" (EU-FamPro; No. 101008404-JUST-AG2020/JUST-JTR- AG-2020) funded by the European Union's Justice Programme (2014-2020). The content of this paper represents only the views of the authors and is their sole responsibility. The European Commission does not accept any responsibility for use that may be made of the information it contains. 


\section{INTRODUCTION}

The idea of party autonomy and the possibility to choose the forum and law in private relations appeared centuries ago. As S. C. Symeonides claims, the first rule recognising party autonomy at the multistate level appeared in a decree issued by Hellenistic Egypt circa 120-188 B.C. In particular, the decree provided that contracts concluded in the Egyptian language were subject to the jurisdiction of Egyptian courts, whereas contracts concluded in Greek language fell under jurisdiction of Greek courts applying Greek law. ${ }^{1}$ In this way, by choosing the language of the contract the parties could directly choose the court and indirectly the applicable law. Later, the idea of party autonomy reappeared in the legal writings of Charles Dumoulin (XVI century, France) and Ulrich Huber (XVII century, the Netherlands). These authors used the presumed intent of the parties as the rationale for arguing against lex loci contractus and in favour of lex loci solutionis. ${ }^{2}$

In the twentieth century, party autonomy became firmly established as a principle of commercial law. This principle is now embedded in national laws and EU instruments and has gained a lot of attention in academic writings. ${ }^{3}$ In the area of family law, however, party autonomy was slower in establishing itself. Taking into account the sensitive nature of family law and especially the states' duty to protect the interests of the child, it was widely accepted that party autonomy in this field should be highly limited. Nevertheless, today we can confidently say that rules foreseeing party autonomy is an increasing trend in the EU private international family law instruments. To a greater or lesser extent, it is mentioned in the Brussels IIa Regulation defining jurisdiction in matrimonial and parental responsibility matters ${ }^{4}$ (recast version will be applied as of August $2022^{5}$ ); the Rome III Regulation ${ }^{6}$ setting out the rules on the choice of law applicable to

\footnotetext{
${ }^{1}$ Symeon C. Symeonides, Choice of Law (Oxford: Oxford University Press, 2016), 362.

2 Ibid.

3 See, e.g. as regards the EU instruments: Mớnica Herranz Ballesteros, "The Regime of Party Autonomy in the Brussels I Recast: The Solutions Adopted for Agreements on Jurisdiction," Journal of Private International Law 10 (2014): 291-308; Jan-Jaap Kuipers, "Party Autonomy in the Brussels I Regulation and Rome I Regulation and the European Court of Justice," German Law Journal 10 (2009): 1505-1525; Theodorus Martinus De Boer, "Party autonomy and its limitations in the Rome II regulation," Yearbook of Private International Law 9 (2007): 19-29; Maya Mandery, Party Autonomy in Contractual and NonContractual Obligations. A European and Anglo-Common Law perspective on the freedom of choice of law in the Rome I Regulation on the law applicable to contractual obligations and the Rome II Regulation on the law applicable to non-contractual obligations (Bern: Peter Lang, 2014); Symeon Symeonides, "Party Autonomy in Rome I and II from a Comparative Perspective": 513-550; in: Katharina BoeleWoelki, Thalia Einhorn, Daniel Girsberger, and Symeon Symeonides, eds., Convergence and Divergence in Private International Law - Liber Amicorum Kurt Siehr (Eleven International Publishing, 2010); etc.

4 Council Regulation (EC) No 2201/2003 of 27 November 2003 concerning jurisdiction and the recognition and enforcement of judgments in matrimonial matters and the matters of parental responsibility, repealing Regulation (EC) No 1347/2000, OJ L 338, 23/12/2003, p. 1-29.

${ }^{5}$ Council Regulation (EU) 2019/1111 of 25 June 2019 on jurisdiction, the recognition and enforcement of decisions in matrimonial matters and the matters of parental responsibility, and on international child abduction, OJ L 178, 2.7.2019, p. 1-115.

${ }^{6}$ Council Regulation (EU) No 1259/2010 of 20 December 2010 implementing enhanced cooperation in the area of the law applicable to divorce and legal separation, OJ L 343, 29.12.2010, p. 10-16.
} 
divorce; the Maintenance Regulation ${ }^{7}$; the Matrimonial Property Regulation ${ }^{8}$ and the Regulation on Property Consequences of a Registered Partnership ${ }^{9}$. In addition, the 2007 Hague Protocol on the law applicable to maintenance obligations ${ }^{10}$ which is directly applicable in the EU, also provides for party autonomy. Party autonomy can furthermore be found in the Succession Regulation, ${ }^{11}$ which is strictly speaking not part of EU private international family law, but is strongly related to it, as presented below in the chapter on jurisdictional rules of the Matrimonial Property Regulation. However, the scope of party autonomy in those instruments varies considerably with some regulations opening only a small window for the parties to agree, while others providing much wider opportunities. Such inconsistency was criticised by a number of scholars recently. ${ }^{12}$

In comparison to other above-mentioned family law instruments, the Matrimonial Property Regulation and its twin brother the Regulation on Property Consequences of a Registered Partnership provide for generous rules as regards party autonomy. ${ }^{13}$ As I. Viarengo notes, party autonomy is the core and the most significant element of the so-called twin regulations on property effects of marriage and registered partnership. ${ }^{14}$ Indeed, the preamble of the Matrimonial Property Regulation mentions the increase of party autonomy as one of its objectives (recital 36) and the regulation elaborates it in its further provisions (Article 7 and Article 22).

\footnotetext{
7 Council Regulation (EC) No 4/2009 of 18 December 2008 on jurisdiction, applicable law, recognition and enforcement of decisions and cooperation in matters relating to maintenance obligations, OJ L 7, 10.1.2009, p. 1-79.

8 Council Regulation (EU) 2016/1103 of 24 June 2016 implementing enhanced cooperation in the area of jurisdiction, applicable law and the recognition and enforcement of decisions in matters of matrimonial property regimes, OJ L 183, 8.7.2016, p. 1-29.

${ }_{9}$ Council Regulation (EU) 2016/1104 of 24 June 2016 implementing enhanced cooperation in the area of jurisdiction, applicable law and the recognition and enforcement of decisions in matters of the property consequences of registered partnerships, OJ L 183, 8.7.2016, p. 30-56. This regulation will not be analysed in more detail here, however, many of the considerations presented in this paper would also be relevant in case of registered partnership.

10 Hague Protocol of 23 November 2007 on the Law Applicable to Maintenance Obligations. Council Decision of 30 November 2009 on the conclusion by the European Community of the Hague Protocol of 23 November 2007 on the Law Applicable to Maintenance Obligations, OJ L 331, 16.12.2009, p. 17-23.

11 Regulation (EU) No 650/2012 of the European Parliament and of the Council of 4 July 2012 on jurisdiction, applicable law, recognition and enforcement of decisions and acceptance and enforcement of authentic instruments in matters of succession and on the creation of a European Certificate of Succession, OJ L 201, 27.7.2012, p. 107-134.

12 Lara Walker, "Party Autonomy, Inconsistency and the Specific Characteristics of Family Law in the EU," Journal of Private International Law Vol. 14, No. 2 (2018) // DOI: 10.1080/17441048.2018.1509973; Felix Maultzsch, "Party Autonomy in European Private International Law: Uniform Principle or Context-Dependent Instrument?" Journal of Private International Law Vol. 12, No. 3, (2016) // DOI: 10.1080/17441048.2016.1257846; Ilaria Viarengo, "Choice of Law Agreements in Property Regimes, Divorce, and Succession: Stress-testing the New EU Regulations," ERA Forum 17 (2016); Patrick R. Wautelet, "Party Autonomy in International Family Relationships: A Research Agenda" (November 2020) // https://ssrn.com/abstract=2589980.

13 The Matrimonial Property Regulation and the Council Regulation on property consequences of registered partnerships are almost identical save that the first applies to marriage and the second to registered partnerships. While this paper focuses on the Matrimonial Property Regulation, much of it is also true for the Regulation on property consequences of registered partnerships.

${ }^{14}$ Ilaria Viarengo, supra note 12.
} 
The extent to which the EU instruments open the door to party autonomy depends on the transaction at issue: in areas where the division or transfer of assets come to focus, party autonomy is wider than, for example, in cases where personal relations are at stake (divorce, parental responsibilities, etc.). For the same reason, party autonomy can also be found in the Succession Regulation. Already its recitals (see Recitals 28, 29, 38, 39 and 40) provide for the possibility of the parties to choose law or a court that has competence in their succession case. $A$ European law-maker was apparently of an opinion that European succession law, just as European family law, is "mature" enough and therefore ready to introduce some party autonomy.

This paper is dedicated to the analysis of party autonomy as provided for in the Matrimonial Property Regulation. Party autonomy is discussed mainly from two angles: (i) right of the parties to agree on the jurisdiction and (ii) the choice of applicable law for resolving matrimonial property issues. ${ }^{15}$ In addition, it scrutinises party autonomy in the Succession Regulation, which partially and indirectly limits party autonomy of spouses within the framework of the Matrimonial Property Regulation. Matrimonial property and succession law are often closely intertwined. In the majority of succession cases, questions regarding the matrimonial property arise. Often, until matrimonial property issues are resolved, it is not clear what the deceased spouse's property is, what is his/her share in the couple's total debt, which are solely his/her debts and so on. Thus, to carry out a succession procedure, it is necessary to first settle the matrimonial property issues.

The Matrimonial Property Regulation is a relatively new instrument, as it fully applies only as of 29 January 2019. As a result, at the moment national case law that would help to deeper analyse the content and the application practice of this regulation is very limited. Moreover, the Matrimonial Property Regulation was so far not interpreted by the Court of Justice of the European Union (CJEU) ${ }^{16}$ and thus many issues remain open to academic discussions are presumptions. However, the Succession Regulation has been applied since 17 August 2015. Not only that, but national courts had many opportunities to apply it, but also the CJEU has already decided on several questions related to it. ${ }^{17}$

\footnotetext{
15 The Matrimonial Property Regulation consist of three main groups of rules. Firstly, it establishes rules that determine the EU country court competent to deal with a case on the couple's property regimes. Secondly, it foresees conflict of law rules regulating the law applicable to the matrimonial property. Lastly, the regulation contains the rules on the intra-EU recognition and enforcement of a decisions. As this paper focuses on the scope of party autonomy in the Matrimonial Property Regulation, it will thus deal with jurisdictional rules and rules of applicable law provided for in the regulation. The rules on recognition and enforcement of a decisions will not be covered here.

16 So far only one CJEU judgement to a certain extent relates to the Matrimonial Property Regulation, in particular to its relation for the Succession Regulation. See Case C-558/16 Mahnkopf, EU:C:2018:138.

17 E.g. Case C-218/16 Kubicka, EU:C:2017:755, Case C-558/16 Mahnkopf, supra note 16, Case C-658/17 WB, EU:C:2019:444.
} 


\section{ENHANCED COOPERATION AND ITS IMPACT ON PARTY AUTONOMY UNDER MATRIMONIAL PROPERTY REGULATION}

The Matrimonial Property Regulation was adopted through the enhanced cooperation mechanism. ${ }^{18}$ Enhanced cooperation is a procedure designed to overcome situations, where a Commission proposal for a certain legal act is blocked by one or more countries who do not wish to be part of the initiative. It allows a group of at least nine EU Member States to implement measures and adopt an act of enhanced cooperation if all Member States fail to reach an agreement. Other EU countries retain the right to join the enhanced cooperation instruments if they later decide so.

The regulations adopted through the enhanced cooperation, apply only in the Member States that have joined it. This is the case with the Matrimonial Property Regulation. ${ }^{19}$ In countries participating in the enhanced cooperation, the Matrimonial Property Regulation replaces the relevant provisions of private international law and is applied directly; private international law rules remain to be applied to situations not covered by the regulation. In those countries, the regulation is applicable to all situations: to disputes with an element from another Member State participating in the enhanced cooperation; to disputes with an element from the Member State not participating in enhanced cooperation; as well as to disputes with an element from a third country. In countries not participating in the enhanced cooperation, the Matrimonial Property Regulations does not apply.

\footnotetext{
18 There were some efforts to regulate this area through The Hague Conference instruments, however, with little success. In 1987, The Hague Convention of 14 March 1978 on the Law Applicable to Matrimonial Property Regimes was adopted // https://www.hcch.net/en/instruments/conventions/fulltext/?cid=87. However, the complexity of international regulation in this area is signified by the fact that only three states became parties to this convention (France, Luxemburg and the Netherlands). In addition, The Hague Convention of 30 June 2005 on Choice of Court Agreements //

https://www.hcch.net/en/instruments/conventions/full-text/?cid=98 in its Art. 2(2)(c) expressly excludes family law matters, including matrimonial property regimes and other rights or obligations arising out of the marriage or similar relationships out of its scope of application. For historical perspective on adoption of the regulation and more extensive analysis of it see Lucia Valentová, "Property Regimes of Spouses and Partners in New EU Regulations - Jurisdiction, Prorogation and Choice of Law," International and Comparative Law Review Vol. 16, No. 2 (2016) // DOI: 10.1515/iclr-20160026.

1918 states in November 2020 (Austria, Belgium, Bulgaria, Croatia, Cyprus, Czech Republic, Finland, France, Germany, Greece, Italy, Luxembourg, Malta, the Netherlands, Portugal, Slovenia, Spain and Sweden). 17 Member States requested the Commission for enhanced cooperation between them in the area of the property regimes of international couples, including both marriages and registered partnerships. Cyprus joined the enhanced cooperation at a later stage. Estonia is planning to take part of the enhanced cooperation concerning both regulations, but has not yet made necessary legal preparations. The other EU countries (Poland, Hungary, Denmark, Ireland, Estonia, Latvia, Lithuania, Slovakia and Romania) do not take part in enhanced cooperation. They continue to apply their national laws. With exception of Ireland and Denmark (which traditionally have the special status with regard to certain EU instruments), the other states that are not participating in the enhanced cooperation most often claim that the main reason is their concern that under the Twin regulations a state that does not recognise same-sex marriage and/or registered partnerships between same-sex couples would have to recognise such unions if they were concluded in other Member States. A similar situation might arise in respect of partnership registered by a heterosexual couple, if their home state does not foresee an option of partnership for a heterosexual couple.
} 
For example, if a court in Spain (the country which participates in the enhanced cooperation) receives an application regarding matrimonial property and the (ex)spouses are nationals of Lithuania (Member State not participating in the enhanced cooperation) or Ukraine (non-EU country), or there is another link to those countries, the court would still apply the Matrimonial Property Regulation to establish its jurisdiction and applicable law. If, however, an application regarding matrimonial property is submitted to a court located in a country which is not participating in the Matrimonial Property Regulation (e.g. Lithuania), the national law of that state will apply.

This directly affects the scope of party autonomy. In particular, if the agreement of the parties on the chosen law does not comply with the lex fori of the State in which the claim is made and which is not participating in the enhanced cooperation, it may be ignored or declared invalid. For example, if under the national law of such State the application of foreign law is not possible and no choice of law is allowed (this was a case, e.g. as regards Cyprus prior to its participation in the Matrimonial Property Regulation), even if the parties have concluded an agreement as regards their matrimonial property regime and have chosen the applicable law, such agreement might be disregarded by the court.

\section{JURISDICTIONAL RULES AND CHOICE OF COURT IN MATRIMONIAL PROPERTY REGULATION AND THE RELATED INSTRUMENTS}

As it is stated in the Explanatory Memorandum of the Matrimonial Property Regulation, ${ }^{20}$ the aim of this Regulation is to enable citizens to have their various related procedures handled by the courts of the same Member State. To this end, the Regulation seeks to concentrate jurisdiction on the matrimonial property regime in the Member State whose courts are handling the succession of a spouse or the divorce, legal separation or marriage annulment. This is reflected in the general rule sets in Articles 4 and 5 of the Matrimonial Property Regulation.

Such concentration seems to be a very logical solution. Linking matrimonial property case to that of succession is reasonable because the line between the matrimonial property issue on one hand and the succession questions or questions regarding the matrimonial matters on the other hand is often blurry. As noted above, once a spouse passes and succession issue is to be resolved, matrimonial property is the first thing that should be divided before proceeding to succession. Granting jurisdiction in matrimonial property to the courts that have jurisdiction in the divorce, legal separation or marriage annulment case also is a natural and in

20 Proposal for a Council Regulation on jurisdiction, applicable law and the recognition and enforcement of decisions in matters of matrimonial property regimes, COM/2016/0106 final - 2016/059 (CNS). 
most cases the optimal solution. It simplifies the situation of the parties and brings clarity to the national courts.

It should furthermore be noted that the cross-links between the regulations (rules linking jurisdiction in matrimonial property cases to jurisdictional rules in the Succession Regulation and the Brussels IIa regulation) seem to be a very positive development. For a long time, EU family law regulations were developed as separate instruments with very little cross-references. However, they do form a pool of rules that are very often interconnected and applied together. The Matrimonial Property Regulation recognizes this and leans on other EU regulations in regard to its provisions on jurisdiction and the relevant connecting factors.

The unity of jurisdiction and coordination among the different legal instruments are, as C. Grieco notes, prioritized to parties' autonomy. ${ }^{21}$ Below, the jurisdictional rules of the Matrimonial Property Regulation, taken together with the relevant rules of the Succession Regulation, the Brussels IIa regulation, are discussed in greater detail.

\subsection{JURISDICTION FOR MATRIMONIAL PROPERTY IN THE EVENT OF} THE DEATH OF ONE OF THE SPOUSES

Article 4 of the Matrimonial Property Regulation provides that a court seized in matters of the succession of a spouse pursuant to the Succession Regulation also has jurisdiction to rule on matters of the matrimonial property regime arising in connection with that succession case. A jurisdiction of the court to rule on matters of matrimonial property regimes is therefore not determined on the basis of the Matrimonial Property Regulation and its connecting factors, but on the basis of the considerably narrower ${ }^{22}$ range of connecting factors of the Succession Regulation. The rule is compulsory and there is no space for party autonomy in this regard. Parties cannot avoid its application when the court proceedings regarding the matrimonial property issue begin if a court of a Member State is already seized in matters of the succession of a spouse. Not only that the provisions of Matrimonial Property Regulation are not used to determine the jurisdiction, but also an agreement of jurisdiction, if previously concluded, is not taken into account.

${ }^{21}$ Cristina Grieco, "The role of party autonomy under the Regulations on matrimonial property regimes and property consequences of registered partnerships. Some remarks on the coordination between the legal regime established by the new regulations and other relevant instruments of European private international law", Cuadernos de Derecho Transnacional Vol. 10, No. 2, (2018): 465 // DOI: $10.20318 /$ cdt.2018.4384.

${ }^{22}$ Initially, the European legislature did not plan to introduce the party autonomy and the possibility of choosing jurisdiction in succession matters. Later, this option was added to the text, but was kept very limited. See the Proposal for a Regulation of the European Parliament and of the Council on jurisdiction, applicable law, recognition and enforcement of decisions and authentic instruments in matters of succession and the creation of a European Certificate of Succession, $\{\operatorname{SEC}(2009) 410\}$ \{SEC (2009)411\} COM/2009/0154 final - COD 2009/0157*. 
The general jurisdictional rule (and at the same time also the only rule with the connecting factor) of the Succession Regulation is that courts of the Member State in which the deceased had his/her habitual residence at the time of death shall have jurisdiction to rule on the succession as a whole (Article 4 of the Succession Regulation). The parties may conclude an agreement on jurisdiction in one situation only: to link the jurisdiction and the applicable law. Where the law chosen by the deceased to govern his / her succession pursuant to Article 22 of the Succession Regulation is the law of a Member State, the parties concerned may agree that a court or the courts of that Member State are to have exclusive jurisdiction to rule on any succession matter (Article 5 of the Succession Regulation). ${ }^{23}$ Additionally, parties can express their will to choose the jurisdiction implicitly. This can happen when a court exercising jurisdiction pursuant to the agreement on jurisdiction realizes that not all the parties to those proceedings were party to the choice-of-court agreement. In such a situation, the court shall continue to exercise jurisdiction if the parties to the proceedings who were not a party to the agreement enter an appearance without contesting the jurisdiction of the court (Article 9 of the Succession Regulation). If these parties object such jurisdiction of the court, the court has to decline its jurisdiction. ${ }^{24}$

Party autonomy in the frame of the Succession Regulation is therefore limited compared to the wide options for (explicit or implicit) agreement on jurisdiction on the basis of the Matrimonial Property Regulation (see its Articles 7 and 8 and subchapter 3.3 below). However, the parties' possibility to agree that the court that has jurisdiction for matrimonial property issues is in the event of the death of one of the spouses limited with the Succession Regulation.

23 See also the Recital 28 of the Succession Regulation. Consequently, with the choice-of-court agreement it is possible to choose only the court/courts of the EU Member State and not of the third country.

${ }^{24}$ For more see Maria Jose Cazorla Gonzáles, Manuela Giobbi, Jerca Kramberger Škerl, Lucia Ruggeri, and Sandra Winkler, eds., Property relations of cross border couples in the European Union (Napoli: Edizioni Scientifiche Italiane, 2020), 109, 110. 


\subsection{JURISDICTION FOR MATRIMONIAL PROPERTY IN CASES OF DIVORCE, LEGAL SEPARATION OR MARRIAGE ANNULMENT}

Article 5 of the Matrimonial Property Regulation provides that a court seized with an application for divorce, legal separation or marriage annulment in accordance with the Brussels IIa Regulation also has jurisdiction to rule on matters of matrimonial property. In this way, the main rule is to connect the divorce, legal separation or marriage annulment proceedings and proceedings on property concentrating them both in one court. ${ }^{25}$

Article 3 of the Brussels IIa Regulation defining jurisdiction in matrimonial cases lists seven alternative jurisdictional criteria. They are divided into two categories: the first group of jurisdictional grounds is based on habitual residence (Article 3 (1) a $)^{26}$, while the second is based on common nationality or domicile (Article 3 (1) b). The jurisdictional grounds are presented as a 'menu of jurisdictions' and there is no hierarchy between them. Therefore, the first to start the case chooses the jurisdiction.

Depending on the jurisdictional ground on the basis of which divorce was started, the Matrimonial Property Regulation provides either for an automatic extension of jurisdiction or requires clear consent of both parties. Automatic extension of jurisdiction to matrimonial property regimes is set for the cases where jurisdiction for divorce is based on the first four criteria of Article 3(1)(a), in particular, when jurisdiction is based on the current or last common habitual residence of spouses, the habitual residence of the respondent, or habitual residence of either of them in the event of a joint application.

However, in cases when the ties between the international jurisdiction and the specific matrimonial property issue are not strong enough, both spouses need to agree to concentrate jurisdiction in this way. In particular, when the divorce court's jurisdiction is based on Article 3(1)(a) fifth and sixth indent (applicant had resided in a Member State for at least a year immediately before the application was made

25 Ratione temporis, jurisdictional rules set in the regulation apply only to court proceedings initiated on or after 29 January 2019 (Article 69 of the regulation).

${ }^{26}$ For the analysis of the concept of 'habitual residence' see, e.g.: Marc-Philippe Weller and Bettina Rentsch, "'Habitual Residence': A Plea for 'Settled Intention'": 171; in: Stefan Leible, ed., General Principles of European Private International Law (Wolters Kluwer, 2016); Agne Limante, "Establishing Habitual Residence of Adults under the Brussels IIa Regulation: Best Practices from National Case-law," Journal of Private International Law Vol. 14, No. 1 (2018) //

https://doi.org/10.1080/17441048.2018.1442128; Thalia Kruger, "Finding a Habitual Residence": 74; in: Ilaria Viarengo and Francesca C. Villata, eds., Planning the Future of Cross Border Families: A Path Through Coordination (Hart Publishing, 2020); Agne Limante and Ivana Kunda, "Jurisdiction in Parental Responsibility Matters"; in: Costanza Honorati, ed., Jurisdiction in Matrimonial Matters, Parental Responsibility and International Abduction. A Handbook on the Application of Brussels IIa Regulation in National Courts (Torino: Peter Lang, 2017). See also CJEU cases: Case C-523/07 A, EU:C:2009:225; Case C-497/10 PPU Mercredi, EU:C:2010:829; Case C-376/14 PPU C, EU:C:2014:2268; Case C-499/15 $W$ and V, EU:C:2017:118; Case C-111/17 PPU OL V PQ, EU:C:2017:436; Case C-512/17 HR, EU:C:2018:513; Case C-393/18 UD v XB, EU:C:2018:835. 
or six months in case of a Member State of his/her nationality), the spouses' agreement is required for the court that has a jurisdiction on divorce to also have jurisdiction on matrimonial property issues. The reason for this rule is the fact that Article 3(1)(a) fifth and sixth indent are often perceived as allowing the spouse who is submitting the divorce claim to choose the jurisdiction closer to him/her, but not to the other spouse. By asking the spouses' consent in such cases, the Matrimonial Property Regulation seeks fairness, in order to limit the benefits for a forum shopper. In other words, in these situations, a choice of jurisdiction for divorce does not result in the choice of jurisdiction for the matrimonial property.

Let's assume that an Italian husband and a Spanish wife get married and live in Italy, then move to Spain. In a few years, the husband moves to Belgium and the wife stays in Spain. After one year in Brussels, the husband files for divorce there. Belgian court would have jurisdiction for divorce under Article 3.1(a) fifth indent of Brussel IIa regulation (the applicant is habitually resident for at least a year immediately before the application is made). However, an extension of Belgian court jurisdiction to matrimonial property matters depends on the agreement of the wife (Article 5(2)(a) of the Matrimonial Property Regulation).

The wife has not been living in Belgium and is not familiar with Belgian law; therefore, she might refuse to agree to Belgian court jurisdiction. Without her agreement, the Spanish courts would have jurisdiction to rule on the couple's property (Article $6(1)(b)$ ), while the Belgian courts would pronounce the divorce.

The spouse's agreement to extend jurisdiction is furthermore required in other cases when the divorce case is based on Article 5 (conversion of legal separation into divorce) or Article 7 (residual jurisdiction) of the Brussels IIa Regulation. Again, this serves the purpose of safeguarding the parties' interests and autonomy.

The jurisdiction attraction described here is also going to be the most commonly used situation in practice. Property relations are usually dealt with at the same time as divorce, legal separation or marriage annulment. Therefore, in a majority of cases, the connecting factors of the Brussels IIa Regulation are used (indirectly) to determine jurisdiction of the court in matrimonial property issues. Only in cases where the concentration will not be possible will the connecting factors listed in the Matrimonial Property Regulation (see Section 3.3. below) be used. The aim of such regulation is not only to lower costs of the procedures but also to ensure consistent court decisions, which is a reasonable goal to follow. 


\subsection{JURISDICTION IN OTHER CASES: THE GATEWAY FOR PARTY} AUTONOMY

If no court of a Member State has jurisdiction pursuant to Article 5 of the Matrimonial Property Regulation ${ }^{27}$ or in other cases than those provided in Article 4 or $5^{28}$, jurisdiction to rule on a matter of the spouses' matrimonial property regime is established under the rules provided for in Article 6 (Jurisdiction in other cases). This article grants jurisdiction in accordance with the following cascade: (i) to the courts of Member State in whose territory the spouses are habitually resident at the time the court is seized; or failing that (ii) in whose territory the spouses were last habitually resident, insofar as one of them still resides there at the time the court is seized; or failing that (iii) in whose territory the respondent is habitually resident at the time the court is seized; or failing that (iv) of the spouses' common nationality at the time the court is seized. The connecting factors, as revealed by the Explanatory Memorandum of the Matrimonial Property Regulation, were chosen because they frequently coincide with the location of the spouses' property.

When no court has jurisdiction pursuant to Articles 4 or 5 and thus Article 6 applies, in order to enhance predictability and the freedom to choose of the spouses, the Matrimonial Property Regulation also provides for a possibility of choice of court (prorogation fori). The parties may conclude such a jurisdictional agreement when the dispute arises. However, often parties do not want to wait until then. Being in a hostile relationship can mean that parties that are not able to solve the matrimonial issues are also not able to agree on jurisdiction. By that time, they might be living in different countries and might therefore have different interests as to which court to choose. In order to avoid such a situation, the parties can conclude a jurisdictional agreement in advance. However, this solution also has some shortcomings. At the time of concluding an agreement on jurisdiction, the parties have a sincere intention to decide on the competent court and to exclude courts of other countries to decide on their (future) matter. At that moment, however, they do not know yet and cannot predict that their matrimonial property matter will be dealt with at the same time as succession proceedings of one of them, their divorce, marriage annulment or their legal separation. At the time of concluding the jurisdiction agreement, the parties, therefore, do not know for sure if their choice regarding the courts' jurisdiction to decide on their property matter will apply.

27 E.g. jurisdiction in a divorce case was based on Article 3(1) fifth or sixth ident and no agreement of the spouses to extend jurisdiction to rule on matrimonial matters was reached.

${ }^{28}$ E.g. if proceedings for the division of the matrimonial property are initiated after the parties have divorced or if the spouses want to change their matrimonial property regime. 
Under Article 7 the parties may agree that (i) the courts of the Member State whose law is applicable ${ }^{29}$, or (ii) the courts of the Member State of the conclusion of the marriage shall have exclusive jurisdiction to rule on matters of their matrimonial property regime. In the first case, parties are allowed to confer jurisdiction to the courts of the country whose law applies to the substance of the matter. This allows parties, as Pietro Franzina put it, ${ }^{30}$ to benefit from typical advantages of the parallelism of forum and ius. The seized court will ultimately be applying its national law, lex fori, avoiding complications related to the application of foreign law. However, to agree on such a jurisdiction, the parties must firstly find out which Member State's law will be applicable in their case. The second option, the possibility of granting jurisdiction to the courts of the state where the marriage was celebrated seems like the last chance to find a closer link between the parties' situation and the case.

Article 7 of the Matrimonial Property Regulation allows for an explicit agreement on jurisdiction, but when an agreement is not explicitly concluded, the same jurisdiction can be agreed on decisively (prorogatio tacita). The court that otherwise could have jurisdiction on the basis of an explicit agreement can also have jurisdiction with indirect agreement of the parties (Article 8). As mentioned, this is possible only when the explicit agreement on jurisdiction is possible - i.e. not in the situations of the attraction of jurisdiction on the basis of the Articles 4 and 5 of the Matrimonial Property Regulation. The only exception is for the courts of the Member State of the conclusion of the marriage - i.e., the jurisdiction of these courts can be agreed on explicitly only.

\section{CHOICE OF APPLICABLE LAW FOR MATRIMONIAL PROPERTY}

The Matrimonial Property Regulation is very open for the parties to choose the law applicable to their matrimonial property regime. While the choice of law (also known as professio juris) existed in most EU jurisdictions, for some of the participating states of Matrimonial Property Regulation the rules as to the choice of law is a novelty. For example, the application of foreign law to matrimonial property disputes in Cyprus was not possible before the Matrimonial Property Regulation and no choice of law was allowed (the law of the forum was always applied). ${ }^{31}$ Choice of

\footnotetext{
29 Articles 22, 26(1)(a) or (b).

30 Pietro Franzina, "Article 7 Choice of court": 85; in: Ilaria Viarengo and Pietro Franzina, The EU Regulations on the Property Regimes of International Couples. A Commentary (Cheltenham: Elgar, 2020).

31 Anna Plevri, "Cyprus": 93; in: Lucia Ruggeri, Ivana Kunda, and Sandra Winkler, eds., Family Property and Succession in EU Member States National Reports on the Collected Data (Rijeka: Sveuciliste u Rijeci, Pravni fakultet, 2019).
} 
the applicable law was also new in international private law in family matters in Greece. ${ }^{32}$

The Matrimonial Property Regulation makes the parties' choice of law the main rule. Only if the parties' choice were not made would the Regulation foresee the rules on applicable law. In accordance with Article 22, parties can opt for (i) the law of the state where both or one of them is habitually resident at the time the agreement is concluded, or (ii) the law of the nationality of either party at the time the agreement is concluded ${ }^{33}$. While a connecting link is required, there are no limitations on the countries whose law could be chosen. Article 22 does not foresee some options that are often present in national laws. There is no option of lex fori on the list in Article 22; there is no possibility to choose lex rei sitae for the immovable property; the parties cannot grant jurisdiction to a state where they intend to be habitually. Moreover, the Matrimonial Property Regulation does not contain a specific provision to coordinate the law applicable to divorce and legal separation to that applied to matrimonial property. However, as noted above, such a rule is foreseen as regards jurisdiction.

Due to the universal application of the Regulation (Article 20), the spouses are free to choose the law of any country in the world: law of a Member State participating in the Regulation, law of a non-participating Member State or even law of a state that is neither in EU nor in Europe. A principle of universal application of the law can also be found in the Succession Regulation (Article 20). Whether a person has chosen the law to govern his succession or not, any law shall be applied in succession matter whether or not it is the law of a Member State.

In comparison to the Matrimonial Property Regulation, the Succession Regulation provides a person with a narrower set of connecting factors to choose the law governing his or her succession. A person has only one option and may only choose the law of the Member State whose nationality he or she possesses at the time of making the choice or at the time of death. ${ }^{34} \mathrm{~A}$ person possessing multiple nationalities may choose the law of any of the States whose nationality he or she possesses at either the time of making the choice or at the time of death (Article 22 of the Succession Regulation). This connecting factor corresponds to one of the two connecting factors for the choice of the applicable law as provided for in the Matrimonial Property Regulation (Article 22). Within the latter, the spouses and

32 Vassiliki Koumpli and Vassiliki Marazopoulou, "Greece": 287; in: Lucia Ruggeri, Ivana Kunda and Sandra Winkler, eds., Family Property and Succession in EU Member States National Reports on the Collected Data (Rijeka: Sveuciliste u Rijeci, Pravni fakultet, 2019).

${ }^{33}$ The Registered Partnership Regulation adds the place of registration of the partnership to this list of connections.

34 When a person chooses the applicable law, such a law then governs his or her succession as a whole (Article 22 of the Succession Regulation). 
future spouses are more flexible as they can also choose the law of the State of the habitual residence of one of them at the time of the conclusion of the agreement.

If the parties' choice is not made, Article 26 of the Matrimonial Property Regulation which regulates the applicable law in the absence of a choice-of-law agreement comes into play. In particular, Article 26 of the Matrimonial Property Regulation provides that when no choice as to the applicable law is made, the applicable law is established on the basis of a cascade of connecting factors. The first of those connecting factors provides that the law applicable to the matrimonial property regime would be that of the spouses' first common habitual residence after the conclusion of the marriage. This provision sounds reasonable if the couple's first habitual residence was in a country of nationality of one of the spouses or at least somewhere in Europe; it might, however, become concerning if the couple had their first home is some more exotic country.

For example, suppose that an Italian man and a Spanish woman got married in Spain on 1 February 201935. Due to wife's work, the spouses moved to live in Brazil for 3 years. In Spring 2022, they return to Spain where soon after they decide to start divorce proceedings. If the spouses have not chosen the law applicable to their matrimonial property, Article 26 of the Matrimonial Property Regulation will be applied. The national court dealing with the case will have to verify what should be considered as the couple's first habitual residence after the marriage (the first connecting factor in the cascade of Article 26). If, according to the court, the couple acquired their habitual residence in Brazil, Brazilian law should be applicable to the matrimonial property division. However, after they return to Spain, Brazilian law has very weak ties with the couple. ${ }^{36}$

It should be noted that the first connecting criterion established in Article 26 (1)(a) of the Matrimonial Property Regulation - the first common habitual residence of the spouses after the marriage - brings additional uncertainty in more complicated situations. The Regulation does not clearly define the precise point in time; it only states that it should be the first habitual residence of the spouses shortly after the marriage (Recital 49). Should this be the place where the spouses start living right away or in a couple of months after the marriage, even if it is only planned to be their home for a short time? How much time can pass between the marriage and the first habitual residence? How should the situation be dealt with in which the spouses live apart for a year or two (e.g. working in different countries) and only then build their common home in one state? What if they work and as a

\footnotetext{
35 Ratione temporis the rules of the regulation on applicable law (chapter III of the regulation) apply only to spouses who marry or who specify the law applicable to the matrimonial property regime after 29 January 2019 (Article 69(3) of the Regulation).

${ }^{36}$ Article 26(3) foresees a rectifying measure for situations where the first habitual residence did not last long and a much longer time was spent by the spouses in another jurisdiction.
} 
consequence live in different countries for all their lives, but only get to move together when they retire after 30 years of marriage? On one hand, opinions can be found in legal theory that a requirement of a first common habitual residence of the spouses has to be fulfilled in a specific number of months after the marriage (e.g. in a three to six months period). ${ }^{37}$ On the other hand, some are of the opinion that a period in which a first common habitual residence of the spouses after the conclusion of the marriage, should not be restricted. ${ }^{38}$ The answer to these questions is important as one should remember that the establishment of first common habitual residence has retroactive effect and it determines the applicable law since the conclusion of the marriage. With no case law available, however, these questions are difficult to answer. It is highly likely that the Court of Justice of the European Union will be called at some point to clarify the concept of the first common habitual residence of the spouses after the marriage in the context of the Matrimonial Property Regulation. Until then, we can only speculate as to its content. The authors of this paper are of the opinion that it would not be a proper solution to establish a month limit that would be applicable to the establishment of the first common habitual residence as the first connecting factor of the Article 26 (1)(a) of the Matrimonial Property Regulation. It is up to the court to decide on the first common habitual residence on the basis of the distinct circumstances in each specific case. However, in our opinion, such a connecting factor cannot be established at any time (i.e. years or even decades) after the conclusion of the marriage. ${ }^{39}$

Since typically spouses do live together after the conclusion of the marriage, the first connecting factor of Article 26 (1)(a) of the Matrimonial Property Regulation is the most commonly used. If this criteria of first habitual residence fails, applicable law would be the law of the spouses' common nationality at the time of the conclusion of the marriage; or, failing that, the law with which the spouses jointly have the closest connection at the time of the conclusion of the marriage, taking into account all the circumstances. ${ }^{40}$ In addition, by way of exception and upon application by either spouse, the court may decide to apply the law of a State where the spouses had their last common habitual residence for a

37 Judita Dolžan, "Uredbi (EU) glede premoženjskopravnih razmerij za mednarodne pare - kolizijska pravila," Odvetnik 2 (2019): 112. See also Claudia Rudolf, "Premoženjska razmerja med zakonci v mednarodnem zasebnem pravu," Podjetje in delo 6-7 (2018): 960.

38 Domenico Damascelli, "Applicable law, jurisdiction, and recognition of decisions in matters relating to property regimes of spouses and partners in European and Italian private international law," Trusts \& Trustees Vol. 25, No. 1 (2018): 6.

39 See also Neža Pogorelčnik Vogrinc, "Applicable law in matrimonial property regime disputes," Zbornik Pravnog fakulteta Sveučilišta u Rijeci Vol. 40, No. 3 (2019): 1081.

40 The third connecting factor - "the closest connection" is very open and undefined. Paula Poretti argues that the reason for such an openness of the connecting factor is the possibility for it to be used for the bulk of different cases with different common links (Paula Poretti, "Odlučivanje o imovinskim odnosima bračnih drugova u ostavinskim postupcima sukladno Uredbi 2016/1103 o bračnoimovinskom režimu," Zbornik Pravnog fakulteta Sveučilišta u Rijeci Vol. 38, No. 1 (2017): 463). 
significantly longer period of time than in the State of their first habitual residence; or the law of the state on which both spouses had relied in arranging or planning their property relations.

To compare the Matrimonial Property Regulation and the Succession Regulation, when the applicable law is not chosen, different connecting factors are provided for the matrimonial property matters on one hand and the succession matters on the other. The Succession Regulation provides for using the law of the State in which the deceased had his last habitual residence (i.e. the habitual residence at the time of death $)^{41}$, while the first connecting factor to determine the applicable law for the matrimonial property issue is the spouses' first common habitual residence after the conclusion of the marriage. If the spouses have moved to another state and changed the habitual residence after the conclusion of the marriage, both of the matters would have to be decided using two different national laws, which may be inconvenient. The solution can be found in the abovementioned Article 26(3) of the Matrimonial Property Regulation, which allows for an exception in the event of the specific procedural activity of either spouse and at the same time when court's discretion is used. The court that has a jurisdiction to rule on matters of the matrimonial property regime may therefore upon application by the spouse decide that the law of a State other than the State of the spouses' first common habitual residence after the conclusion of the marriage shall govern the matrimonial property regime. To use this option, the applicant has to demonstrate that: (a) the spouses had their last common habitual residence in that other State for a significantly longer period of time than in the State of the first common habitual residence; and (b) both spouses had relied on the law of that other State in arranging or planning their property relations.

The court procedure in matters of the succession of a spouse attracts the jurisdiction to rule on matters of the matrimonial property regime arising in connection with that succession case (Article 4 of the Matrimonial Property Regulation). Due to the difference in connecting factors in Article 21 of the Succession Regulation and in Article 26 of the Matrimonial Property Regulation and due to the possibility that parties choose applicable law of different states, it can easily happen that the court that has a jurisdiction to rule on both matters has to apply legal regulations of two different states. This can happen if choice-of-law

41 Differently than Matrimonial Property Regulation, the Succession Regulation provides for only one connecting factor when no choice-of-law agreement exists. In such a situation, the law applicable to the succession as a whole shall be the law of the State in which the deceased had his habitual residence at the time of death (Article 21 (1) of the Succession Regulation). An exception to this general rule is possible when it is clear from all the circumstances of the case that, at the time of death, the deceased was manifestly more closely connected with a State other than the State whose law would be applicable under above-mentioned rule. In such a case, the law applicable to the succession shall be the law of that other State with which a deceased was manifestly more closely connected (Article 21 (2)). 
agreements exist regarding both of the subject matters or with even higher likelihood in the event of none or only one choice-of-law agreement.

For example, suppose that the spouses' first common habitual residence after the conclusion of the marriage is in Spain. Eight years later they move to Italy and a year after that the wife dies. With regard to the Article 4 of the Succession Regulation, the courts of the Member State in which the deceased had her habitual residence at the time of death shall have jurisdiction to rule on the succession as a whole. Italian courts, therefore, have jurisdiction for the succession case. With regard to the Article 21(1) of the Succession Regulation, Italian courts have to apply the law of the State in which the deceased had her habitual residence at the time of death - i.e. the Italian law. The surviving husband wants to initiate the court procedure regarding the contentious matrimonial property questions. Due to Article 4 of the Matrimonial Property Regulation and its attraction of jurisdiction, Italian courts also have jurisdiction to rule on matters of the matrimonial property regime arising in connection with that succession case. The law applicable for the matrimonial property is determined with regard to the Article 26(1) of the Matrimonial Property Regulation, i.e. the law of the State of the spouses' first common habitual residence after the conclusion of the marriage. As a consequence, an Italian court, deciding on the matter on succession on the basis of Italian law, has to apply Spanish law when deciding on the matrimonial property issue.

What we see from the above is that in more complicated life scenarios, especially when the parties move between jurisdictions, the rules allowing for party autonomy become particularly important. Party autonomy in such cases permits a certain and predictable regulation of family relations. It enables planning in advance and avoiding unnecessary litigation as to jurisdiction or applicable law.

\section{CONCLUDING REMARKS}

Party autonomy is an important tool in private international law, including in family law matters. As individuals receive increasingly more autonomy and powers through different mechanisms and European regulations, we can confidently claim that (future) spouses have obtained a credible possibility to influence the jurisdiction of courts and the law applied in their matrimonial property cases.

However, in real life matrimonial property matters almost never emerge as independent problems. Typically, they are tightly bound with succession procedures in respect of deceased spouses or with the dissolution of marriages (i.e. divorce, either legal separation or marriage annulment). These are the real-life situations in which matrimonial property problems arise most often. 
When dealing with European private international family law, we therefore necessarily need to take into account all of these related aspects and interactions among various legal instruments. Consequently, party autonomy in the Matrimonial Property Regulation is not as autonomous as we would think when reading its provisions in isolation. When talking about the jurisdiction, party autonomy of (future) spouses is de facto greatly limited. The jurisdiction in matrimonial property matters can be granted to the courts that have jurisdiction in the divorce, legal separation or marriage annulment, or in the event of death, to the court seized in matters of the succession of a spouse. This is in practise an optimal solution, primarily preventing contradictory court decisions.

Even when having the full option to conclude a choice-of-court agreement on the basis of the Matrimonial Property Regulation, it is possible that such party autonomy will not come to life. A superior objective of the concentration of jurisdiction is pursued and it is, therefore, necessary to take into account the relevant provisions of the Succession Regulation and the Brussels IIa Regulation. When the (future) spouses do conclude the jurisdiction agreement in advance, these supplementary provisions, therefore, prevent them from knowing for certain whether their agreement on jurisdiction will later really apply.

As regards spouses' autonomy to choose applicable law for matrimonial property disputes, it is much wider, since the Matrimonial Property Regulation brings the parties' choice as the main connecting factor. While this is good news for the parties, it can bring challenges for national courts. The courts might be required to apply law of two or more countries (not necessarily EU Member States) in the same case, thus complicating resolution of the dispute in question. Additionally, the situation can be even more complex, because the Matrimonial Property Regulation does not provide for coordination between the law applicable to divorce and legal separation and the law applied in the court proceedings regarding the matrimonial property.

Only for the situations when the parties did not choose a law does the Regulation foresee the rules on applicable law. The Regulation provides for a cascade of connecting factors, some of which raise a number of questions. The first of connecting factor, i.e. spouses' first common habitual residence after the conclusion of the marriage, can pose serious challenges if the spouses live outside of Europe after they marry. This refers to the use of the law of a third country, which can pose a problem to the court and also might not be in the interest of both parties. Similarly, the question arises as to how to decide on the applicable law if the spouses do not live together for a while after the marriage. Setting a specific length of time in which the first common habitual residence is supposed to be 
established, is, in our opinion, not an ideal solution. Nevertheless, such a connecting factor cannot be established years or even decades after the marriage.

In view of the context and insights of this article, it is obvious that the construction of a coherent and duly integrated EU legal system for the resolution of family-related disputes remains a work in progress. May our article be considered a modest building block in this immense and long-term effort.

\section{BIBLIOGRAPHY}

1. Ballesteros, Mớnica Herranz. "The Regime of Party Autonomy in the Brussels I Recast: The Solutions Adopted for Agreements on Jurisdiction." Journal of Private International Law 10 (2014): 291-308.

2. Cazorla Gonzáles, Maria Jose, Manuela Giobbi, Jerca Kramberger Škerl, Lucia Ruggeri, and Sandra Winkler, eds. Property relations of cross border couples in the European Union. Napoli: Edizioni Scientifiche Italiane, 2020.

3. Damascelli, Domenico. "Applicable law, jurisdiction, and recognition of decisions in matters relating to property regimes of spouses and partners in European and Italian private international law." Trusts \& Trustees Vol. 25, No. 1 (2018): 6-16.

4. De Boer, Theodorus Martinus. "Party autonomy and its limitations in the Rome II regulation." Yearbook of Private International Law 9 (2007): 19-29.

5. Dolžan, Judita. "Uredbi (EU) glede premoženjskopravnih razmerij za mednarodne pare - kolizijska pravila". Odvetnik 2 (2019): 106-113.

6. Franzina, Pietro. "Article 7 Choice of court": 85-92. In: Ilaria Viarengo and Pietro Franzina. The EU Regulations on the Property Regimes of International Couples. A Commentary. Cheltenham: Elgar, 2020.

7. Grieco, Cristina. "The role of party autonomy under the Regulations on matrimonial property regimes and property consequences of registered partnerships. Some remarks on the coordination between the legal regime established by the new regulations and other relevant instruments of European private international law." Cuadernos de Derecho Transnacional Vol. 10, No. 2, (2018): 457-476//

DOI: $10.20318 /$ cdt.2018.4384.

8. Koumpli, Vassiliki, and Vassiliki Marazopoulou. "Greece": 287-310. In: Lucia Ruggeri, Ivana Kunda, and Sandra Winkler, eds. Family Property and Succession in EU Member States National Reports on the Collected Data. Rijeka: Sveucíliste u Rijeci, Pravni fakultet, 2019. 
9. Kruger, Thalia. "Finding a Habitual Residence": 74-89. In: Ilaria Viarengo and Francesca C. Villata, eds. Planning the Future of Cross Border Families: A Path Through Coordination. Hart Publishing, 2020.

10. Kuipers, Jan-Jaap. "Party Autonomy in the Brussels I Regulation and Rome I Regulation and the European Court of Justice." German Law Journal 10 (2009): 1505-1525.

11. Limante, Agne, and Ivana Kunda. "Jurisdiction in Parental Responsibility Matters": 61-91. In: Costanza Honorati, ed. Jurisdiction in Matrimonial Matters, Parental Responsibility and International Abduction. A Handbook on the Application of Brussels IIa Regulation in National Courts. Torino: Peter Lang, 2017.

12. Limante, Agne. "Establishing Habitual Residence of Adults under the Brussels IIa Regulation: Best Practices from National Case-law." Journal of Private International Law Vol. 14, No. 1 (2018): 160-181// https://doi.org/10.1080/17441048.2018.1442128.

13. Mandery, Maya. Party Autonomy in Contractual and Non-Contractual Obligations. A European and Anglo-Common Law perspective on the freedom of choice of law in the Rome I Regulation on the law applicable to contractual obligations and the Rome II Regulation on the law applicable to noncontractual obligations. Bern: Peter Lang, 2014.

14. Maultzsch, Felix. "Party Autonomy in European Private International Law: Uniform Principle or Context-Dependent Instrument?" Journal of Private International Law Vol. 12, No. 3 (2016): 466-491 //

DOI: $10.1080 / 17441048.2016 .1257846$.

15. Plevri, Anna. "Cyprus": 93-122. In: Lucia Ruggeri, Ivana Kunda, and Sandra Winkler, eds. Family Property and Succession in EU Member States National Reports on the Collected Data. Rijeka: Sveuciliste u Rijeci, Pravni fakultet, 2019.

16. Pogorelčnik Vogrinc, Neža. "Applicable law in matrimonial property regime disputes." Zbornik Pravnog fakulteta Sveučilišta u Rijeci Vol. 40, No. 3 (2019): 1075-1096//

DOI: $10.30925 /$ zpfsr.40.3.5.

17. Poretti, Paula. "Odlučivanje o imovinskim odnosima bračnih drugova u ostavinskim postupcima sukladno Uredbi 2016/1103 o bračnoimovinskom režimu." Zbornik Pravnog fakulteta Sveučilišta u Rijeci Vol. 38, No. 1 (2017): 449-471.

18. Rudolf, Claudia. "Premoženjska razmerja med zakonci $v$ mednarodnem zasebnem pravu." Podjetje in delo 6-7 (2018): 952-963. 
19. Symeonides, Symeon C. Choice of Law. Oxford: Oxford University Press, 2016.

20. Symeonides, Symeon C. "Party Autonomy in Rome I and II from a Comparative Perspective": 513-550. In: Katharina Boele-Woelki, Thalia Einhorn, Daniel Girsberger, and Symeon Symeonides, eds. Convergence and Divergence in Private International Law - Liber Amicorum Kurt Siehr. Eleven International Publishing, 2010.

21. Valentová, Lucia. "Property Regimes of Spouses and Partners in New EU Regulations - Jurisdiction, Prorogation and Choice of Law." International and Comparative Law Review Vol. 16, No. 2 (2016): 221-240 //

DOI: $10.1515 /$ iclr-2016-0026.

22. Viarengo, Ilaria. "Choice of Law Agreements in Property Regimes, Divorce, and Succession: Stress-testing the New EU Regulations." ERA Forum 17 (2016): 543-554.

23. Walker, Lara. "Party Autonomy, Inconsistency and the Specific Characteristics of Family Law in the EU." Journal of Private International Law Vol. 14, No. 2 (2018): 225-261 //

DOI: $10.1080 / 17441048.2018 .1509973$.

24. Wautelet, Patrick R., "Party Autonomy in International Family Relationships: A Research Agenda" (November 2020) //

https://ssrn.com/abstract=2589980.

25. Weller, Marc-Philippe, and Rentsch, Bettina. "'Habitual Residence': A Plea for 'Settled Intention'": 171-187. In: Stefan Leible, ed. General Principles of European Private International Law. Wolters Kluwer, 2016.

\section{LEGAL REFERENCES}

1. Case C-497/10 PPU Mercredi. EU:C:2010:829.

2. Case C-111/17 PPU OL v PQ. EU:C:2017:436.

3. Case C-218/16, Kubicka. EU:C:2017:755.

4. Case C-376/14 PPU C. EU:C:2014:2268.

5. Case C-393/18 UD v XB. EU:C:2018:835.

6. Case $C-499 / 15 W$ and V. EU:C:2017:118.

7. Case C-512/17 HR. EU:C:2018:513.

8. Case C-523/07 A. EU:C:2009:225.

9. Case C-558/16 Mahnkopf. EU:C:2018:138.

10. Case C-658/17 WB. EU:C:2019:444.

11. Council Regulation (EC) No 2201/2003 of 27 November 2003 concerning jurisdiction and the recognition and enforcement of judgments in matrimonial 
matters and the matters of parental responsibility, repealing Regulation (EC) No $1347 / 2000$. OJ L 338, 23/12/2003, p. 1-29

12. Council Regulation (EC) No 4/2009 of 18 December 2008 on jurisdiction, applicable law, recognition and enforcement of decisions and cooperation in matters relating to maintenance obligations. OJ L 7, 10.1.2009, p. 1-79.

13. Council Regulation (EU) 2016/1103 of 24 June 2016 implementing enhanced cooperation in the area of jurisdiction, applicable law and the recognition and enforcement of decisions in matters of matrimonial property regimes. OJ $\mathrm{L}$ $183,8.7 .2016$, p. 1-29.

14. Council Regulation (EU) 2016/1104 of 24 June 2016 implementing enhanced cooperation in the area of jurisdiction, applicable law and the recognition and enforcement of decisions in matters of the property consequences of registered partnerships. OJ L 183, 8.7.2016, p. 30-56.

15. Council Regulation (EU) 2019/1111 of 25 June 2019 on jurisdiction, the recognition and enforcement of decisions in matrimonial matters and the matters of parental responsibility, and on international child abduction. OJ L $178,2.7 .2019$, p. 1-115.

16. Council Regulation (EU) No 1259/2010 of 20 December 2010 implementing enhanced cooperation in the area of the law applicable to divorce and legal separation. OJ L 343, 29.12.2010, p. 10-16.

17. Hague Convention of 14 March 1978 on the Law Applicable to Matrimonial Property Regimes // https://www.hcch.net/en/instruments/conventions/full-text/?cid=87.

18. Hague Convention of 30 June 2005 on Choice of Court Agreements // https://www.hcch.net/en/instruments/conventions/full-text/?cid=98.

19. Hague Protocol of 23 November 2007 on the Law Applicable to Maintenance Obligations. Council Decision of 30 November 2009 on the conclusion by the European Community of the Hague Protocol of 23 November 2007 on the Law Applicable to Maintenance Obligations. OJ L 331, 16.12.2009, p. 17-23.

20. Proposal for a Council Regulation on jurisdiction, applicable law and the recognition and enforcement of decisions in matters of matrimonial property regimes. COM/2016/0106 final - 2016/059 (CNS).

21. Proposal for a Regulation of the European Parliament and of the Council on jurisdiction, applicable law, recognition and enforcement of decisions and authentic instruments in matters of succession and the creation of a European Certificate of Succession. \{SEC(2009) 410\} \{SEC (2009)411\} COM/2009/0154 final - COD 2009/0157*. 
22. Regulation (EU) No 650/2012 of the European Parliament and of the Council of 4 July 2012 on jurisdiction, applicable law, recognition and enforcement of decisions and acceptance and enforcement of authentic instruments in matters of succession and on the creation of a European Certificate of Succession. OJ L 201, 27.7.2012, p. 107-134. 